\title{
An Empirical Investigation of the Relationships between Motivation and Athlete Performance Mediated by Self-Talk: Evidence from Combat Sports ${ }^{*}$
}

\author{
Erkan Bingöl1 ${ }^{1 D}$, Suleyman Murat Yildiz ${ }^{\dagger 1}$ (D) \\ ${ }^{1}$ Mugla Sitki Kocman University, Mugla, Turkey
}

Original Article

Received: 03.03.2021
Accepted: 23.04.2021
DOI: $10.25307 /$ jssr.890794

Online Publishing: 30.06 .2021

\begin{abstract}
Self-talk, which has attracted more attention lately, is an effective psychological instrument used alongside physical training in sports. Hence, the purpose of this study was to explore the relationships between motivation and performance, focusing primarily on the mediating role of self-talk. In this study, which included 325 athletes from Boxing, Muay Thai, Kickboxing, Wushu, and Taekwondo branches, three scales were used to collect data. To measure self-talk, The Self-Talk Questionnaire (S-TQ) developed by Zervas, Stavrou, and Psychountaki (2007), to measure motivation, The Sports Motivation Scale-II (SMSII) developed by Pelletier et al. (2013) were used. The performance scale for athletes was specifically developed in this study and labeled as Athlete Performance Scale for Combat Sports (APS-CS) (see Appendix). The results of the study indicated statistically significant relationships among motivation, self-talk, and performance. More specifically, motivation was found to have a significant positive relationship with self-talk and performance. Self-talk, on the other hand, had a significant positive relationship with performance and partially mediated the relationship between motivation and performance.
\end{abstract}

Keywords: Motivation, Self-Talk, Athlete Performance, Combat Sports.

\section{Kendinle Konuşmanın Aracılık Etkisi ile Motivasyon ve Sporcu Performansı Arasındaki İlişkilerin Ampirik Bir İncelemesi: Dövüş Sporlarından Kanıtlar}

\section{$\ddot{\mathbf{O} z}$}

Son zamanlarda spor literatüründe daha fazla ilgi gören kendinle konuşma, sporda fiziksel antrenmanın yanında kullanılan etkili bir psikolojik araçtır. Bu nedenle, bu çalışmanın amacı, öncelikle kendinle konuşmanın aracı rolüne odaklanarak, motivasyon ve performans arasındaki ilişkileri araştırmaktır. Boks, Muay Thai, Kickboks, Wushu ve Taekwondo branşlarından 325 sporcunun katıldığı bu çalışmada veri toplamak için üç ayrı ölçek kullanılmıştır. Kendinle konuşmayı ölçmek için Zervas, Stavrou ve Psychountaki (2007) tarafından geliştirilen Kendinle Konuşma Ölçeği, motivasyonu ölçmek için Pelletier ve diğerleri (2013) tarafından geliştirilen Spor Motivasyon Ölçeği-II kullanılmıştır. Sporcular için performans ölçeği, bu çalışmada özel olarak geliştirilmiş ve Sporcu Performansı Ölçeği-Dövüş Sporları (SPÖ-DS) olarak adlandırılmıştır (bakınız Ek). Çalışmanın sonuçları, motivasyon, kendinle konuşma ve performans arasında istatistiksel olarak anlamlı ilişkiler olduğunu göstermiştir. Daha spesifik olarak, motivasyonun kendinle konuşma ve performansla anlamlı ve pozitif bir ilişkiye sahip olduğu görülmüştür. Kendinle konuşma ise performansla anlamlı pozitif bir ilişkiye sahiptir ve motivasyon ile performans arasındaki ilişkiye kısmen aracılık etmiștir.

Anahtar Kelimeler: Motivasyon, Kendinle Konuşma, Sporcu Performansı, Dövüş Sporları.

\footnotetext{
* This paper was summarized from the first author's PhD Thesis.

${ }^{\dagger}$ Corresponding Author: Prof. Dr. Suleyman M. Yildiz, E-mail: smyildiz@ gmail.com
} 


\section{INTRODUCTION}

Particularly functions of sports such as providing economic benefits, providing status, and advertising are forcing individuals and teams to perform high. Nowadays, although physical training methods are used to increase the performance of athletes, some psychological techniques are additionally used as these methods are not sufficient on their own (Latinjak, Ramis, Hatzigeorgiadis, and Torregrosa, 2018). One of these is the self-talk technique, which has recently become popular (Hatzigeorgiadis, Zourbanos, Mpoumpaki, and Theodorakis, 2009). Therefore, this study focused on motivation and performance, as well as self-talk, and addressed the relationships between these three topics.

Vygotsky (1986) distinguished between at least two forms of language, "social speech" and "private speech", in the theory of verbal self-regulation, in which people propose cognitive developments to use language as a tool of thought. Being one of the first verbal self-regulation theories that distinguish speech and self for others, this theory reflects two different functions of the language, communicative and regulatory. In fact, Vygotsky pointed out in this theory that the person self-talk with his/her private speech. Hackfort and Schwenkmezger (1993) proposed that self-talk was a "dialogue [through which] the individual interprets feelings and perceptions, regulates and changes evaluations and convictions, and gives him/herself instructions and reinforcement" (p. 355). According to this definition, the person both speaks to him/herself and listens to him/herself. Self-talk was defined by Theodorakis et al. (2000) as "what people say to themselves either out loud or as a small voice inside their head" (p. 254). This definition emphasizes two important aspects of self-talk. First, self-talk can be said openly or privately. Second, self-talk consists of phrases that appeal to oneself, not to others (Hardy, 2006).

The self-talk contains the functions that the athlete will serve him/herself. Hardy, Gammage, and Hall (2001) suggested that athletes' self-talk content could be divided into four special dimensions: Nature, perspective, structure, and person. The nature dimension means positive self-talk ("I can do this") and negative self-talk ("I cannot do this"). The perspective dimension is bidirectional: internal and external self-talk - that is, self-talk is spoken aloud inside or outside the person's head. The structure dimension is formed of cue words ("Punch!"), phrases ("Keep punch tight"), and full sentences ("I can knock my punch on the opponent's chin") categories. Finally, the person dimension means self-talk said in first-person ("I can do it") or second-person ("You can do it"). Self-talk is a mechanism that brings athletes more effort. Studies on self-talk showed that prepared athletes as mentally (Theodorakis, Hatzigeorgiadis, and Chroni, 2008) and task-specific self-talking had a beneficial effect on physical performance (Gibson and Foster, 2007). Previous research found that successful athletes could use more self-talk than unsuccessful athletes. In addition, individual sports athletes stated that they used more self-talk functions according to team sports (Hardy, Hall, and Hardy, 2005).

Motivation is the process of acting in order to meet the needs with the effect of a motive. Motive is the force that drives an individual to a behavior. Individuals exhibit conscious behaviors with the effect of motivation (Yildiz, 2017). This concept is used to explain the reasons of individual behavior and activity. Motivation researches in the work environment explain what powers make an individual act and in what way this activity is performed (Salkauskiene and Vveinhardt, 2007). Similarly, during training and competition in sports organizations, athletes 
act consciously with the effect of motivation. Motivation is of two types: intrinsic motivation and extrinsic motivation. Intrinsic motivation is the motives that come from within the athlete and to meet his personal needs. For example, the desire to experience a sense of success, the desire to reach high status, etc. Extrinsic motivation is the motives that activate the athlete with the help of environmental stimuli. For example, winning medals, earning money, etc. Both types of motivation are effective in athlete performance. Performance is a concept that quantitatively and qualitatively indicates how much an athlete achieved the goal. There is a lot of evidence that motivation is effective in athlete performance (Gillet et al., 2012). Together with external sources of motivation (reward, status, coach, spectator, etc.), athletes can find the opportunity to raise their performance to the top by using self-talk as the source of intrinsic motivation. The results of researches about self-talk showed positive effects on performance (Tod, Hardy, and Oliver, 2011). For instance, it has been found that self-talk in individual sports (Ming and Martin, 1996) and team sports (Johnson, Hrycaiko, Johnson, and Halas, 2004) has a positive effect on the performance of athletes. In the literature, studies on self-talk in combat sports are limited (Blumenstein, Lidor, and Tenenbaum, 2005; Slimani et al., 2014). In addition, there is no study that deals with motivation, self-talk, and athlete performance at the same time. In order to contribute to the sports literature, our study aimed to explore the relationships between motivation and performance by considering self-talk as a mediator. For this purpose, the following hypotheses have been developed:

$\mathrm{H}_{1}$ : Motivation has a significant and positive effect on the athletes' self-talk.

$\mathrm{H}_{2}$ : Motivation has a significant and positive effect on the athletes' performance.

$\mathrm{H}_{3}$ : Self-talk has a mediating effect between motivation and the athletes' performance.

\section{METHOD}

\section{Research Model}

The model of this study, which was carried out to examine the relationships among motivation, self-talk, and athlete performance, is presented in Figure 1. This model demonstrates the causeand-effect relationship among the variables; that is, the effect of the independent variable to the mediating variable, the independent variable to the dependent variable, and the effect of the mediating variable to the dependent variable. In this model, when the effect of the mediating variable is controlled, the level of the relationship between independent and dependent variables is examined. If the relationship level is low and the significance continues, there is "partial mediation"; if the relationship has no significance, there is "full mediation". On the other hand, the level of significance between the mediating variable and the dependent variable should be maintained (Baron and Kenny, 1986).

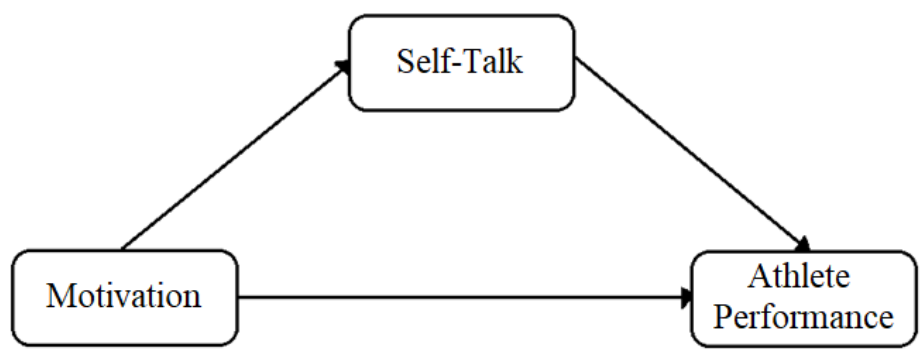

Figure 1. A model of relationships among motivation, self-talk, and athlete performance. 


\section{Participants}

In this study, the convenience sampling method was used. In the scientific research process, because it is difficult to reach the entire universe in terms of time, cost, and labor such a method was preferred. This study focused on the branches included Boxing, Muay Thai, Kickboxing, Wushu, and Taekwondo in Intercollegiate Championships organized by the Turkish University Sports Federation. The sample of the study were 325 athletes (138 women and 187 men) who participated in these championships. Participation was voluntary and random.

\section{Measurement Instruments}

In this study, three measurement instruments were used: The Self-Talk Questionnaire (S-TQ), the Sports Motivation Scale-II (SMS-II), and the Athlete Performance Scale for Combat Sports (APS-CS). The S-TQ developed by Zervas, Stavrou, and Psychountaki (2007) and adapted to Turkish by Engür (2011) was used to measure athletes' self-talk levels. To measure the motivation of the athletes, the SMS-II developed by Pelletier et al. (2013) and adapted to Turkish by Öcal and Sakallı (2018) was used. The scales were rated on a 7-point Likert-type scale ranging from 1 ("never") to 7 (“always").

In order to measure the performance of athletes, the APS-CS which was specially developed in this study was used. This scale is based on the athlete's perception of her/his own performance. The development process of this scale is detailed below.

\section{Generation of the Athlete Performance Scale for Combat Sports}

We have used a convergent interviewing method to elicit the information needed, as proposed by Carson, Gilmore, Perry, and Gronhaug (2001). They argued that such a method was useful in the early stages when it was aimed at investigating the goal of learning and identifying issues of high importance for the targeted sample. They define this process as a "cyclic series of indepth interviews" where researchers use an unstructured approach and begin interviewing by asking broad and open questions. After a few repetitions, the interviewers examine their questions to reach the specific questions required to investigate the phenomenon of research.

As Carson et al. (2001) suggested, in order to develop the scale that will determine the athlete's performance, 5 athletes were randomly selected from each of the branches of Boxing, Muay Thai, Kickboxing, Wushu, and Taekwondo, and later in-depth interviews were held with 25 athletes. First, an opening question was asked to athletes: "how do you express your performance to evaluate?". Afterward, the responses were collected in the item pool and similar ones were combined. For example, the statement "I best apply the techniques in competitions" and the statement "I best apply the tactics in competitions" are arranged as "I best apply the techniques and tactics in competitions". As a result of consecutive interviews, the statements ended when they reached the saturation point. The number of items agreed for athlete performance was 7. In addition, these items have been examined by 6 field experts from each branch for content validity, and have been made into application forms after minor corrections have been made. As a result, this scale was labeled as "Athlete Performance Scale for Combat Sports (APS-CS)", (see Appendix). All scale items consist of Likert type ranges ("1 = Never", "7 = Every time"). 


\section{Research Ethic}

Ethical approval was given to this study by the Ethics Committee of Mugla Sitki Kocman University, Turkey (Decision number: 85; protocol number: 180089; meeting date: May 24, 2018).

\section{Data Collection}

This study was approved by the Human Research Ethics Committee of Mugla Sitki Kocman University, Turkey. The participants were composed of athletes competing in intercollegiate competitions. Therefore, in order to implement the questionnaire to athletes, the researcher received permission from the Presidency of the Turkish University Sports Federation.

\section{Statistical Analyses}

Descriptive statistics, exploratory and confirmatory factor analysis, Cronbach's Alpha coefficient, correlation analysis, and hierarchical regression analysis were used in this study.

\section{RESULTS}

\section{Demographic Properties}

We ran descriptive analyses to understand the demographic profile of the sample. The results showed that $42.5 \%$ of the participants were women, $57.5 \%$ were male, and $36.3 \%$ of the participants are boxers, $33.5 \%$ are kickboxers, $4.3 \%$ are muay thai fighters, $20.9 \%$ are taekwondo athletes, and $4.9 \%$ are wushu athletes. It was determined that the average age of the participants was $21.8 \pm 3.49$, and the duration of the sports was $7.7 \pm 5.15$ (years).

\section{Test for Validity and Reliability}

Since validity analyses were performed in previous studies for SMS-II and S-TQ, only reliability analyses were performed in this study. On the other hand, both validity and reliability analyses were performed for APS-CS because it was developed specifically for this study.

The reliability analysis using the Cronbach's alpha coefficient indicated a high-reliability score of 0.77 for the SMS-II, 0.918 for the S-TQ, and 0.812 for the APS-CS. Since APS-CS was developed specifically in this study, exploratory factor analysis was conducted. First, the suitability of the scale for factor analysis was examined by Kaiser-Meyer-Olkin (KMO) and Bartlett's Sphericity test. The KMO value (0.824) resulting from the test is excellent and Bartlett's Sphericity test is significant $\left(\chi^{2}=678.369 ; \mathrm{df}=21 ; \mathrm{p}=0.000\right)$. All these values indicate that the scale is suitable for factor analysis. Second, with the varimax rotation applied to the scale, it was observed that the items were unidimensional as a result of the analysis of the main components. The factor loads of the items in the dimension vary between 0.548 and 0.786 (Table 1). All these values show that APS-CS is a valid scale for combat sports. 
Bingöl, E. and Yildiz, S.M. (2021). An Empirical investigation of the relationships between motivation and athlete performance mediated by self-talk: Evidence from combat sports. Journal of Sport Sciences Researches, 6(1), 1323.

Table 1. Validity results of the APS-CS

\begin{tabular}{lrcc}
\hline Items & M & Sd & $\begin{array}{c}\text { Factor } \\
\text { Loading }\end{array}$ \\
\hline I best apply the techniques and tactics in competitions & 5.30 & 1.36 & .665 \\
I usually take the first three places in competitions & 4.87 & 1.94 & .763 \\
I win the game by the number & 4.78 & 1.84 & .618 \\
I win the game by knockout & 4.06 & 1.95 & .661 \\
My superior performance gives the spectator pleasure & 5.11 & 1.65 & .786 \\
I usually leave as happy after competitions & 5.14 & 1.62 & .763 \\
I'm a good athlete & 6.02 & 1.32 & .548 \\
\hline & Percentage of Variance Explained & 47.776 \\
& Cumulative \% of Variance Explained & 47.776 \\
& KMO & .824 \\
\hline
\end{tabular}

\section{Correlation Analysis}

Table 2 shows the correlations between the variables. Accordingly, there is a significant and positive relationship between motivation and self-talk $(\mathrm{r}=0.245)$, and between motivation and performance $(r=0.245)$. Similarly, there is a significant and positive relationship between selftalk and performance $(r=0.188)$.

Table 2. Results of correlation analysis

\begin{tabular}{lcc}
\hline Variables & Motivation & Self-talk \\
\hline Motivation & 1 & \\
Self-talk & $.245^{* *}$ & 1 \\
Performance & $.245^{* *}$ & $.188^{* *}$ \\
\hline${ }^{* *}$ Correlation is significant at the $p<0.01$ level & &
\end{tabular}

\section{Hierarchical Regression Analysis}

Table 3 shows the hierarchical regression analysis in which self-talk is modeled as a mediating variable. While "motivation" is an independent variable in Model 1, "self-talk" is a dependent variable; while "motivation" is an independent variable in Model 2, "performance" is a dependent variable; In Model 3, "motivation" and "self-talk" are analyzed as independent variables and "performance" dependent variable. Result of the analysis, it was observed that the value of the motivation, which was 0.245 in Model 2, decreased to 0.215 in Model 3, but its significance continued. The continuity of the significance of the beta value, however, the fact that the mediating variable retains its significance indicates that self-talk had a partial mediating effect between motivation and performance. According to these results, all research hypotheses were accepted. 

performance mediated by self-talk: Evidence from combat sports. Journal of Sport Sciences Researches, 6(1), 1323.

Table 3. Hierarchical regression analysis with self-talk as a mediating variable

\begin{tabular}{lccc}
\hline Variables & Self-talk & Performance & Performance \\
\cline { 2 - 4 } Model 1 & $\boldsymbol{\beta}$ & $\boldsymbol{\beta}$ & $\boldsymbol{\beta}$ \\
Motivation & & & \\
$F$ & $.245^{* *}$ & & \\
$R^{2}$ & 20.633 & & \\
Adjusted $R^{2}$ & .060 & & \\
\hline Model 2 & .057 & $.245^{* *}$ & \\
Motivation & & 20.567 & .060 \\
$F$ & & .057 & $.211^{* *}$ \\
$R^{2}$ & & & $.136^{*}$ \\
Adjusted $R^{2}$ & & & 13.913 \\
\hline Model 2 ve Model 3 & & & .077 \\
Motivation & & .072 \\
Self-talk & & & \\
$R^{2}$ & & & \\
Adjusted $R^{2}$ & & \\
\hline${ }^{*} p<0.05 ;{ }^{* *} p<0.01$ & & \\
\end{tabular}

\section{DISCUSSION AND CONCLUSION}

The sports literature reports that both motivation and self-talk have a positive effect on an athlete's performance. However, there is no research in the literature examining the triple connections of these variables. Therefore, our study was designed to reveal the relationships between motivation and athlete performance and present the results to the sports literature by focusing on the mediating effect of self-talk.

There is quite a lot of research in the sports literature on motivation, self-talk, and athlete performance. For instance, Chantal, Guay, Dobreva-Martinova, and Vallerand (1996) examined the relationship between motivation and performance on top athletes consisting of canoeists, biathletes, figure skaters, boxers, tennis players, and skiers. As a result of their studies, the researchers found that motivation had a positive effect on athlete performance. Hatzigeorgiadis, Galanis, Zourbanos, and Theodorakis (2014) in their research on young swimmers and athletes stated that positive self-talk helped them concentrate and enhanced their motivation. Van Raalte, Brewer, Rivera, and Petitpas (1994) found that self-talk in their study on junior tennis players had a positive effect on the athletes' performance. Perkos, Theodorakis, and Chroni (2002) performed a self-talk training program in young basketball players and observed that the use of self-talk improved players' dribbling and passing performance. DiazOcejo, Kuitunnen, and Mora-Merida (2013), in their research on endurance athletes, found that self-talk can mediate cognitive processes in order to enhance aerobic endurance.

The results of our study show that the variables of motivation, self-talk, and performance are related to each other on combat athletes. Motivation is significant and positively associated with both self-talk and athlete performance. In addition, self-talk has a significant and positive relationship with athlete performance. To sum up, these three variables examined in our study 
support the previous research results in terms of the direction and significance of the relationships between each other.

Unlike other researches, a unique contribution to our study is to consider and evaluate self-talk as a mediator variable. According to the result of our study, self-talk shows a partial mediating effect between motivation and athlete performance. That is, while athlete performance can be directly affected by motivation, it can also be affected by self-talk. The impact of self-talk on performance is low compared to motivation. This shows that self-talk is a side mechanism of motivation. In summary, it can be said that in some cases, only motivation can be effective on the performance of athletes, in some cases, the combination of motivation and self-talk can be effective.

As a result, in addition to using extrinsic sources of motivation to increase the performance of athletes in training and competitions, self-talk can be used as intrinsic motivation. Expressions directed to him/herself by the athlete can contribute to reaching the peak of the performance.

Conflicts of Interest: The authors declare that they have no conflict of interest.

Author Contributions: Both authors have made a substantial and intellectual contribution to the study and approved it for publication.

\section{Research Ethic}

Ethics Committee : Ethics Committee of Mugla Sitki Kocman University, Turkey

Date : May 24, 2018

Decision / Protocol number : 85/180089 
Bingöl, E. and Yildiz, S.M. (2021). An Empirical investigation of the relationships between motivation and athlete performance mediated by self-talk: Evidence from combat sports. Journal of Sport Sciences Researches, 6(1), 1323.

\section{REFERENCES}

Baron, R.M. and Kenny, D.A. (1986). The moderator-mediator variable distinction in social psychological research: Conceptual, strategic, and statistical considerations. Journal of Personality and Social Psychology, 51(6), 1173-1182. https://doi.org/10.1037/0022-3514.51.6.1173

Blumenstein, B., Lidor, R. and Tenenbaum, G. (2005). Periodization and planning of psychological preparation in elite combat sport programs: The case of judo. International Journal of Sport and Exercise Psychology, 3(1), 7-25. https://doi.org/10.1080/1612197X.2005.9671755

Carson, D., Gilmore, A., Perry, C. and Gronhaug, K. (2001). Qualitative marketing research. London: Sage.

Chantal, Y., Guay, F., Dobreva-Martinova, T. and Vallerand, R.J. (1996). Motivation and elite performance: An explatory investigation with Bulgarian athletes. International Journal of Sport Psychology, 27(2), 173-182.

Diaz-Ocejo, J., Kuitunnen, S. and Mora-Merida, J.A. (2013). An intervention to enhance the performance of a 3000 metre steeplechase athlete with the use of segmentation and self-talk. Journal of Sport Psychology, 22(1), 87-92.

Engür, M. (2011). Performans başarısızlı̆̆ değerlendirme envanteri ve kendinle konuşma anketinin Türk sporcu popülasyonu'na uyarlanması ve uygulanması. Yayımlanmamış Doktora Tezi, Ege Üniversitesi, İzmir.

Gibson, A.S.C. and Foster, C. (2007). The role of self-talk in the awareness of physiological state and physical performance. Sports Med, 37, 1029-1044. https://doi.org/10.2165/00007256-200737120-00003

Gillet, N., Berjot, S., Vallerand, R.J., Amoura, S. and Rosnet, E. (2012). Examining the motivation-performance relationship in competitive sport: A cluster-analytic approach. International Journal of Sport Psychology, 43, 79-102.

Hackfort, D. and Schwenkmezger, P. (1993). Anxiety. In R.N. Singer, M. Murphey, \& L.K. Tennant, (Eds.). Handbook of research on sport psychology (pp. 328-364). New York: Macmillan.

Hardy, J. (2006). Speaking clearly: A critical review of the self-talk literature. Psychology of Sport and Exercise, 7(1), 81-97. https://doi.org/10.1016/j.psychsport.2005.04.002

Hardy, J., Gammage, K. and Hall, C.R. (2001). A description of athlete self-talk. The Sport Psychologist, 15(3), 306-318. https://doi.org/10.1123/tsp.15.3.306

Hardy, J., Hall, C.R. and Hardy, L. (2005). Quantifying athlete self-talk. Journal of Sports Sciences, 23(9), 905917. https://doi.org/10.1080/02640410500130706

Hatzigeorgiadis, A., Zourbanos, N., Mpoumpaki, S. and Theodorakis, Y. (2009). Mechanism underlying the selftalk performance relationship: The effects of motivational self-talk on self-confidence and anxiety. Psychology of Sport and Exercise, 10(1), 186-192. https://doi.org/10.1016/j.psychsport.2008.07.009

Hatzigeorgiadis, A., Galanis, E., Zourbanos, N. and Theodorakis, Y. (2014). Self-talk and competitive sport performance. Journal of Applied Sport Psychology, 26(1), 82-95. https://doi.org/10.1080/10413200.2013.790095

Johnson, J.J.M., Hrycaiko, D.W., Johnson, G.V. and Halas, J.M. (2004). Self-talk and female youth soccer performance. The Sport Psychologist, 18(1), 44-59. https://doi.org/10.1123/tsp.18.1.44

Latinjak, A.T., Ramis, Y., Hatzigeorgiadis, A. and Torregrosa, M. (2018). Sport self-talk: An interpretative review. Journal of Sport Psychology, 27(2), 75-86.

Ming, S. and Martin, G.L. (1996). Single-subject evaluation of a self-talk package for improving figure skating performance. The Sport Psychologist, 10(3), 227-238. https://doi.org/10.1123/tsp.10.3.227

Öcal, K. and Sakall1, D. (2017). Turkish adaptation of the Sport Motivation Scale II (Sms-II): Procedures of validity and reliability. International Journal of Sport, Exercise and Training Sciences, 4(1), 38-49. https://doi.org/10.18826/useeabd.327789 
Bingöl, E. and Yildiz, S.M. (2021). An Empirical investigation of the relationships between motivation and athlete performance mediated by self-talk: Evidence from combat sports. Journal of Sport Sciences Researches, 6(1), 1323.

Pelletier, L.G., Rocchi, M.A., Vallerand, R.J., Deci, E.L. and Ryan, R.M. (2013). Validation of the revised sport motivation scale (SMS-II). Psychology of Sport and Exercise, 14(3), 329-341. https://doi.org/10.1016/j.psychsport.2012.12.002

Perkos, S., Theodorakis, Y. and Chroni, S. (2002). Enhancing performance and skill acquisition in novice basketball players with instructional self-talk. The Sport Psychologist, 16(4), 368-383. https://doi.org/10.1123/tsp.16.4.368

Salkauskiene, L. and Vveinhardt, J. (2007). The influence of motivation system factors on the employees in Siauliai Companies. Journal of Young Scientists, 1(12), 227-233.

Slimani, M., Hentati, A., Bouazizi, M., Boudhiba, D., Amar, I.B. and Chéour, F. (2014). Effects of self-talk and mental training package on self-confidence and positive and negative affects in male kickboxers. Journal of Humanities and Social Science, 19(5), 31-34. https://doi.org/10.9790/0837-19513134

Theodorakis, Y., Weinberg, R., Natsis, P., Douma, I. and Kazakas, P. (2000). The effects of motivational and instructional self-talk on improving motor performance. The Sport Psychologist, 14(3), 253271. https://doi.org/10.1123/tsp.14.3.253

Theodorakis, Y., Hatzigeorgiadis, A., and Chroni, S. (2008). Self-talk: It works, but how? Development and preliminary validation of the functions of self-talk questionnaire. Measurement in Physical Education and Exercise Science, 12(1), 10-30. https://doi.org/10.1080/10913670701715158

Tod, D., Hardy, J. and Oliver, E. (2011). Effects of self-talk: A systematic review. Journal of Sport and Exercise Psychology, 33(5), 666-687. https://doi.org/10.1123/jsep.33.5.666

Van Raalte, J.L., Brewer, B.W., Rivera, P.M. and Petitpas, A.J. (1994). The relationship between observable selftalk and competitive junior tennis players' match performances. Journal of Sport and Exercise Psychology, 16(4), 400-415. https://doi.org/10.1123/jsep.16.4.400

Vygotsky, L.S. (1986). Thought and language (A. Kozulin, Trans.). Cambridge: MIT Press.

Yildiz, S.M. (2017). Orgutsel davranis: Secme Konular. [Organzational behaviour: Selected topics]. Ankara: Detay Yayınevi.

Zervas, Y., Stavrou, N.A. and Psychountaki, M. (2007). Development and validating of the self-talk questionnaire. Journal of Applied Sport Psychology, 19(2), 142-159. https://doi.org/10.1080/10413200601185156 
Bingöl, E. and Yildiz, S.M. (2021). An Empirical investigation of the relationships between motivation and athlete performance mediated by self-talk: Evidence from combat sports. Journal of Sport Sciences Researches, 6(1), 1323.

\begin{tabular}{|l|l|l|l|l|l|l|}
\hline APPENDIX - Athlete Performance Scale for Combat Sports (APS-CS) & \\
\hline & & & \\
& & & \\
\end{tabular}

Key:

1 - Never

2 - Rarely, in less than $10 \%$ of the chances when I could have

3 - Occasionally, in about $30 \%$ of the chances when I could have

4 - Sometimes, in about $50 \%$ of the chances when I could have

5 - Frequently, in about $70 \%$ of the chances when I could have

6 - Usually, in about $90 \%$ of the chances I could have

7 - Every time

EK - Sporcu Performansı Ölçeği-Dövüş Sporları (SPÖ-DS)

\begin{tabular}{|c|c|c|c|c|c|c|c|}
\hline & 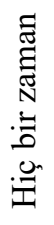 & 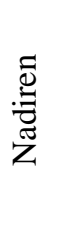 & 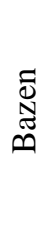 & 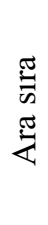 & $\frac{\frac{\pi}{\frac{\pi}{3}}}{\frac{\pi}{\pi}}$ & $\frac{\frac{0}{v}}{\stackrel{0}{0}}$ & 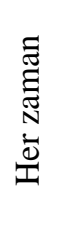 \\
\hline 1. Müsabakalarda teknik-taktikleri en iyi şekilde uygularım & 1 & 2 & 3 & 4 & 5 & 6 & 7 \\
\hline 2. Müsabakalarda genellikle dereceye girerim (ilk 3) & 1 & 2 & 3 & 4 & 5 & 6 & 7 \\
\hline 3. Müsabakaları çoğunlukla sayı ile kazınırım & 1 & 2 & 3 & 4 & 5 & 6 & 7 \\
\hline 4. Müsabakaları çoğunlukla nakavtla kazanırım & 1 & 2 & 3 & 4 & 5 & 6 & 7 \\
\hline 5. Performansım ile müsabakayı seyir zevkine ulaştırırım & 1 & 2 & 3 & 4 & 5 & 6 & 7 \\
\hline 6. Müsabakalardan genellikle mutlu ayrılırım & 1 & 2 & 3 & 4 & 5 & 6 & 7 \\
\hline 7. Ben iyi bir sporcuyum & 1 & 2 & 3 & 4 & 5 & 6 & 7 \\
\hline
\end{tabular}

Except where otherwise noted, this paper is licensed under a Creative Commons Attribution 4.0 International license. 